\title{
SUPERVISI UNTUK PENGEMBANGAN KEMAMPUAN GURU PEMBAWA PENINGKATAN KUALITAS PENDIDIKAN SISWA
}

\author{
Lillah Fitri \\ lillahfitri01@gmail.com
}

\begin{abstract}
ABSTRAK
Kualitas belajar siswa dan output dari hasil pelajaran di seklah yang ada di indonesia. Hal ini karena masih kurangnya kemapuan guru sebagai tenaga pendidik. Guru memiliki peranan yang sangat pending, di pundaknya di bebankan tanggung jawab atas mutu pendidikan. Supervisi pendidikan merupakan cara yang dapat mengembangkan atau meningkatkan kemapuan dan kreatifitas guru di dalam menyampaikan materi pembelajaran. Sehingga dengan adanya dapat juga di artikan sebagai metode pemberian layanan atau memberikan bantuan pembenaan dari supervisor ke pada guru untuk meningkatkan kualitas pendidikan siswa. Dengan pengadaan supervisi ini dapat meningkatkan kemampuankemampuan yang terpendam dalam diri pendidik teruutamanya guru. Dari hasil supervisi nantinya dapat menghasilkan tenaga pendidik yang berkualitas yang dapat menghasilkan siswa yang berilmu pengetahuan.
\end{abstract}

Kata kunci : guru, supervisi pendidikan

\section{LATAR BELAKANG}

Indonesia merupakan negara yang sangat luas, dangan segala tumbuhan dan hewan yang ada didalamnya indonesia dikatan negara yang sangat makmur dalam sumber daya alam. Namun, kemakmuran ini belum diimbangi dengan kemampuan dari sumber daya manusia untuk memanfaatkan segala kelebiahn yang ada di indonesia ini. Untuk pengembangan sumberdaya manusia ini, perlunya suatu sistem yang dapat meningkatkan pendidikan nasional. Menurut (Hadi Fatkhurokhim, 2016) menyampaikan bahwa dalam praktik pendidikan yang paling di perlukan itu adalah pendidikan dasr yang dapat menunjang pendidikan di tingkat yang lebih tinggi. Pendidikan dasar juga merupakan tempat pembentukan karakter dari siswa, dimana karakter yang kita inginkan adalah pendidikan yang dapat meningkatkan keimanan dan ketakwaan serta akhlak mulia dalam rangka mencerdaskan kehidupan bangsa yang di ataur dalam undang-undang.

Dengan terus berkembangnya ilmu pengetahuan dan teknologi seharusnya mutu pendidikan semakin meningkat pesat. Namun nyatanya mutu pendidikan semakin berkurang yang dapat di lihat dari hasil 3 lierasi berikut (1) Gambaran hasil studi TIMSS tahun 2007 memperlihatkan bahwa, pencapaian skor matematika anak Indonesia 405 sedangkan skor rata-rata internasional adalah 500. Pencapaian ranking anak Indonesia dalam bidang matematika berada pada urutan ke-36 dari 49 negara peserta. Sedangkan dalam bidang sains, pencapaian skor sains anak Indonesia adalah 433, sedangkan skor rata-rata internasional adalah 500. Ranking anak Indonesia dalam bidang sains berada pada posisi ke 35 dari 49 negara peserta.(2)Gambaran hasil studi PISA tahun 2006 memperlihatkan bahwa, pencapaian skor matematika anak Indonesia 393 (skor rata-rata internasional = 429). Ranking anak Indonesia dalam bidang matematika berada pada urutan ke-50 dari 57 negara peserta. Selanjutnya skor yang dicapai anak Indonesia dalam bidang sains juga masih dibawah ratarata skor internasional, yakni 395 (skor rata-rata internasional adalah 451. Pencapaian ranking anak Indonesia dalam bidang sains berada pada urutan ke-53 dari 57 negara peserta. Kemampuan anak Indonesia dalam bidang literasi membaca adalah 395, dan skor rata-rata 
internasional adalah 430. Pencapaian ranking anak Indonesia dalam bidang literasi membaca berada pada urutan ke-48 dari 56 negara peserta. (3)Gambaran hasil studi PIRLS memperlihatkan bahwa Skor prestasi membaca rata-rata siswa Indonesia adalah 407, menduduki posisi ke lima dari urutan bawah, di atas Qatar (353), Kuwait (330), Maroko (323), dan Afrika Selatan (302). Rata-rata prestasi membaca internasional adalah 500 (Tjalla).

Rendahnya prestasi belajar siswa berkaitan dengan kurangnya kemapuan guru dalam mengajak siswa untuk mencintai pelajaran. Guru hanya menekankan bahwa siswa harus paham dengan materi pembelajaran, bukan memberikan pengarahan pada siswa agar mencintai pelajaran dan menikmati semua yang ada di dalamnya. Menurut (Sabandi, 2013) menyampaikan bahwa kualitan pendidikan di indonesia masih minim. Hai ini di sebabkan oleh guru merupakan sumber utama gabi siwa untuk mendapatkan materi pembelajaran. Padalah dengan perkembangan ilmu pengetahuan dan teknologi yang semakin cangih, seharusnya siswa bisa mendapatkan sumber informasi materi pembelajaran yang lebih banyak, terutama dengan adanya internet. Di internet siswa dapat mencari apapun dengan lebih mudah di tambah lagi dengan penjelasan diri vidio-vidio yang telah di buat oleh yang ahli di bidangnya.

Di samping itu Sabandi (2013), juga membandingkan kenapa mutu pendidikan di indonesia masih sangat rendah, yang di sebabkan oleh beberapa faktor: (1) masih adanya budaya menggunakan buku paket, buku paket boleh di gunakan sebagai rujukan, namun bukan berarti buku paket yang memiliki kendali kemana pembelajaran yang harusnya di sampaik oleh guru. Padahal pada beberapa buku paket tidak mengandung kompetensi dasar yang telah di berikan pemerintah pada sekolah. (2) budaya pengajaran satu arah yang berpusat pada guru, sehingga siswa terkesan menjadi mangkok kosong yang akan diisi oleh guru, sedangkan seharusnya dalam pembelajaran siswa seidaknya memiliki sedikit pengetahuan agar timbulnya tanya jawab dalam pembelajaran yang akan membuat materi pembelajaran bertahan lebih dalam dan siswa menjadi lebih mengerti. (3) kurangnya sarana dan prasana, hal ini tak dapat di pungkiri lagi karena ketidak merataanya sarana di daerah terpencil dengan di perkotaan memberikan efek pada pemahaman siswa terhadap materi pembelajaran.

Supervisi memiliki peranan penting dalam meningkatkan kualitas pendidikan siswa, karena pada proses supervisi guru memiliki peluang yang sangat besar dalam mengembangan kemampuan dan keterampilannya. Dalam proses ini guru di awasi oleh supervisor, dima supervisor di sekolah dapat seorang kepala sekolah atau pengawas. Supervisi yang di jalankan oleh sepala sekolah ini di atau di dalam Permen Diknas Nomor 13 Tahun 2017.

Berdasarkan uraian di atas, permasalahan tulisan ini adalah bagaimana proses supervisi pendidikan yang dapat mengoptimalkan kemampuan guru agar menghasilkan siswa yang berkualitas?. Tujuan tulisan ini adalah mengetahui proses supervisi pendidikan yang dapat mengoptimalkan kemampuan guru agar menghasilkan siswa yang berkualitas.

\section{PEMBAHASAN}

\section{Supervisi Pendidikan}

Pendapat (Suryani, 2016) meyampakain bahwa pengertian supervisi yang berkaitan dengan pendidkan merupakan pembinaan kepada guru. Namun secara tradisional supervisi diartikan sebagai inspeksi. Dalam pengertian lainnya supervisi di artikan sebagai peningkatan makna dari inspeksi yang di bermakna mencari-cari keslahan. Hal ini tentunya tidak sesuai dengan makna supervisi yang sebenarnya. Dan juga tidak sesuai dengan perkembangan ilmu pengetahun sekarang ini.

Menurut (Sola, 2018), menyatakan bahwa supervisi berupa suatu pelayanan yang diberikan kepada guru agar guru dapat mengembangkan diri, memiliki pengetahuan tentang 
pendidikan, mengetahui kekurangan-kekurangnya selama pembelajaran selama ini serta mendapatkan solusi untuk melengkapi kekurangan-kekurang tersebut untuk meningkatkan proses blajar mengajar, dimana dalam proses supervisi ini guru akan di awasi dan dibimbing oleh superviso. Supervisor di sekolah dapat berupa seorang kepala sekolah taupun pengawas.

Manun pengertian supervisi oleh Sabandi (2013), menyampain hal yang lebih berkembang dan sesuai dengan perkembangan zaman dimana yang pada mulanya berupa inspeksi yang jerjadinya oteriter oleh supervisor, namun sekarang antara supervisor dengan guru telah membentuk kolaborasi bertujuan untuk bertanggung jawab dan berinisiatif untuk meningkatkan kualitas pembelajaran, dan menumbuhkan budaya belajar pada guru, agar guru dapat terus berkembang dengan berkembangnya zaman untuk mengimbangi pengetahun yang harus di dapat siswa.

\section{Pelaksanaan Supervisi}

Berdasarkan penjabaran (Slameto, 2017), dalam penyusunan program supervisi perada beberapa aspek yang harus di prioritaskan untuk membentuk sekolah yang efektif : (1) adanya kepemimpinan yang bersifat profesional, (2) berfokus pada pembelajarn dan metode pembelajaran yang efektif untk mencapai indikator yang telah di buat, (3) berorientasi pada visi, misi dan tujuan sekolah, (4) memberikan harapan yang tinggi bagi seluruh siswa, (5) menciptakan warga sekolah yang gemal belajar untuk mengikuti perkembangan zaman dan pengetahuan, (6) memberikan stimulasi dari lingkungan sekolah agar tercipta pembelajaran yang menyenangkan. Keterampilan dan kemampuan sangat dibutuhkan dalam menentukan faktor atau pun kondisi supervisi yang efektif. Untuk itu kepala sekolah sebagai supervisor harus memilki kemampuan dalam menentukan faktor yang sesuai dengan keadaan tertentu sehingga akan memberikan hasil yang maksimal.

Utuk melakukan supervisi harus adanya beberapa pendekatan yang dapat membantu dalam menjalankan supervisi. Berdasarkan penjabaran Sabandi (2013), ada tiga pendekatan supervisi, yang lebih populer dikenal dengan supervisi klinis, pengembangan dan diferensial.

a. Supervisi klinis

Supervisi klinis lebih menekankan pada pertemuan tatap muka antara supervisor dengan guruuntuk membahas data-data yang telah di kumpulkan dari setiap kelas. Jika di emukan kesalah atau kekurang-kekurang pada hasil pembelajaran maka di adannya pengkajian terhadap sumberdari terjadinya masalah dan mencarikan solusi terbaik untuk memperbaiki masalah. Pada supervisi klinis ini guru berfokus menjadi agen pemberi perubahan pada siswa.

b. Supervisi pengembangan

Supervisi pengembangan ini memperlakukan guru sebagai individu yang berbeda. Hal ini di kuatkan oleh setiap individu pemiliki pengalaman dan keterampilan yang berbeda-beda sehingga pendekatan terhadap tiap guru juga berbeda-beda.

c. Supervisi diferensial

Superfisi diferensial merupakan supervisi yang paling baru. Pada supervisi ini di berikan beberapa jenis supervisi yang sesuai untuk masing-masing individu. Supervisi ini terbentuk karena perbedaan pendekatan antasa satu orang dengan supervisor mau pun guru.

Ada jenis pendekatan lain yang dinilai lebih efektif dan mampu memberikan hasil yang lebih efektif adalah dengan pendekapan pelatihan. Seperti yang di jabarkan oleh Sabandi (2013), pelatihan merupan proses untuk mengembangan anggota pelatihan. Tidak hanya itu pada pendekatan pelatihan adanya tranfer kemampuan dari pelatih ke peserta pelatihan, sehingga peserta pelatiha lebih mampu dalam memahami kondisi dan situasi yang terjadi dan cara untuk menyelesaikan permasalah di lapangan nantinya. Dan pada pelatihan adanya praktik yang di berikan pada peserta pelatihan berupa permasalahan-permasalahan 
dimana peserta pelatihan dituntut untuk mampu menyelesaikan permasalah dengan metodemetode yang telah di ajarkan sebelumnya.

Sabandi (2013) juga menyampaikan beberapa alasan kenapa pendekatan pelatihan harus diadakan : meningkatkan semangat pada guru karena mendapat pengalaman baru, mendapat motivasi untuk melakukan perubahan kearah yang lebih baik, meningkatkan efisiensi waktu dengan metode-metode pembelajaran yang lebih kreatif, meningkatkan citra sekolah dengan keberhasilan dalam mengajar.

\section{KESIMPULAN}

Proses supervisi pendidikan yang dapat mengoptimalkan kemampuan guru adalah dengan adanya kemampuan dari supervisor untuk menentukan prioritas yang harus di utamakan dan pengambilan keputusan dari supervisor dalam keadaan tertentu menentukan pendekatan-pendekatan yang akan mampu memberikan hasil yang lebih baik pada hasil belajar siswa di sekolah.

\section{SARAN}

Supervisi pendidikan memangsangat di butuhkan untuk meningkatkan kualitas tenaga pendidik dan juga meningkatkan kinerja pendidik dalam mengajar di dalam kelas agar terciptanya generasi yang memiliki kemampuan spiritua dan emosional yang baik dalam menerima pembelajaran dari pendidik. Supervisi ini juga dapat memberikan dampak yang besar jika di jalankan dan di implementasikan dengan baik oleh guru kepada siswa dan juga adanya pengawasan yang baik oleh kepala sekolah yang berfungsi sebagai supervisor. Berdasarkan penjabaran dan kesimpulan yang telah saya paparkan sebelumnya. Saya sangat berharap adanya supervisi yang lebih baik yang tidak menekan ruang gerak peserta didik oleh supervisor yang disini adalah kepala sekolah

\section{REFERENSI}

Hadi Fatkhurokhim. (2016). PENGARUH PELAKSANAAN SUPERVISI PENDIDIKAN TERHADAP KINERJA GURU DI SEKOLAH DASAR. Jurnal Pendidikan Guru Sekolah Dasar, (3), 114-120.

Sabandi, A. (2013). Supervisi Pendidikan Untuk Pengembangan Profesionalitas Guru Berkelanjutan. Jurnal Ilmiah Ilmu Pendidikan, XIII(2), 1-9.

Slameto, S. (2017). Supervisi Pendidikan Oleh Pengawas Sekolah. Kelola: Jurnal Manajemen Pendidikan, 3(2), 192. https://doi.org/10.24246/j.jk.2016.v3.i2.p192-206

Sola, E. (2018). Ada Apa Dengan Supervisi Pendidikan? Jurnal Idaarah, II(1), 130-140.

Suryani, C. (2016). Implementasi Supervisi Pendidikan Dalam Meningkatkan Proses Pembelajaran Di Min Sukadamai Kota Banda Aceh. Jurnal Ilmiah Didaktika, 16(1), 23. https://doi.org/10.22373/jid.v16i1.585

Tjalla, A. Potret Mutu Pendidikan Indonesia Ditinjau dari Hasil-hasil Studi Internasional. Universitas Negeri Jakarta 